\title{
Simultaneous Determination of Palladium, Platinum and Rhodium by On-Line Column Enrichment and HPLC with 2,4-Dihydroxybenzylidenethiorhodanine as Pre-Column Derivatization Reagent
}

\author{
Xuechang Dong, ${ }^{a}$ Yong Han, ${ }^{a}$ Qiufen Hu, ${ }^{a, b}$ Jing Chen ${ }^{b}$ and Guangyu Yang ${ }^{*, b}$ \\ ${ }^{a}$ Department of Chemistry, Yunnan Institute of the Nationalities, Kunming, 650031, P.R. China \\ ${ }^{b}$ Department of Chemistry, Yunnan University, Kunming, 650091, P.R. China
}

\begin{abstract}
Um novo método para determinação simultânea de íons paládio, platina e ródio, como quelatos metal-DHBTR foi desenvolvido. Os íons paládio, platina e ródio foram derivatizados (pré-coluna) com 2,4-dihidroxibenzilidenotiorodanina (DHBTR) para formar quelatos coloridos. Os quelatos Pd-DHBTR, Pt-DHBTR e Rh-DHBTR são absorvidos na coluna de enriquecimento, quando injetados e transportados por uma fase móvel composta por solução tampão de ácido acético-acetato de sódio $0,05 \mathrm{~mol} \mathrm{~L}^{-1}(\mathrm{pH} 3,5)$. Após o término do enriquecimento, ao acionar uma válvula de seis vias, os quelatos retidos foram carregados pela fase móvel, para a coluna analítica. A separação dos quelatos na coluna analítica foi satisfatória com acetonitrila $62 \%$ (v/ v) (contendo solução tampão de ácido acético-acetato de sódio $\left(0,05 \mathrm{~mol} \mathrm{~L}^{-1}, \mathrm{pH} 3,5\right)$ e $0,1 \%$ $(\mathrm{m} / \mathrm{v})$ de tritonX-100) como fase móvel. Os limites de detecção de paládio, platina e ródio são 3,6 ng L ${ }^{-1}, 3,2 \mathrm{ng} \mathrm{L}^{-1}$ e 4,5 ng L ${ }^{-1}$, respectivamente. Este método foi aplicado para a determinação de paládio, platina e ródio em água, urina e amostras de solo, com bons resultados.
\end{abstract}

A new method for the simultaneous determination of palladium, platinum and rhodium ions as metal-DHBTR chelates was developed. The palladium, platinum and rhodium ions were pre-column derivatized with 2,4-dihydroxybenzylidenethiorhodanine (DHBTR) to form colored chelates. The Pd-DHBTR, Pt-DHBTR and Rh-DHBTR chelates can be absorbed onto the front of the enrichment column when they were injected into the injector and sent to the enrichment column with a $0.05 \mathrm{~mol} \mathrm{~L}^{-1}$ sodium acetate-acetic acid buffer solution ( $\mathrm{pH}$ 3.5) as mobile phase. After the enrichment had finished, by switching the six ports switching valve, the retained chelates were back-flushed by mobile phase and traveling towards the analytical column. These chelates separation on the analytical column was satisfactory with $62 \%(\mathrm{v} / \mathrm{v})$ acetonitrile (containing $0.05 \mathrm{~mol} \mathrm{~L}^{-1}$ of $\mathrm{pH} 3.5$ sodium acetate-acetic acid buffer salt and $0.1 \%(\mathrm{~m} / \mathrm{v})$ of tritonX-100) as mobile phase. The Limits of detection of palladium, platinum and rhodium are $3.6 \mathrm{ng} \mathrm{L}^{-1}, 3.2 \mathrm{ng} \mathrm{L}^{-1}$ and $4.5 \mathrm{ng} \mathrm{L}^{-1}$, respectively. This method was applied to the determination of palladium, platinum and rhodium in water, urine and soil samples with good results.

Keywords: palladium, platinum, rhodium, 2,4-dihydroxybenzylidenethiorhodanine, high performance liquid chromatography, on-line enrichment

\section{Introduction}

Environmental contamination by the platinum group elements (PGEs), mainly related to automotive catalytic converters, is exponentially increasing and reliable and accurate quantification is a mandatory task. ${ }^{1-4}$ The wide use of palladium, platinum and rhodium not only in automotive catalytic converters but as a drug $(\mathrm{Pt})$ and in food production (Pd) ${ }^{5}$ has led to a more uncontrolled

*e-mail: huqiufena@163.com release of those metals in the environment, with respect to the one due to the traditional chemical industry. Moreover, the platinum group elements derived from automotive catalytic converters are released as nanocrystallites (particles with less than $3 \mathrm{~mm}$ in diameter) due to thermal cracking of the catalyser structure and to mechanical abrasion. ${ }^{6,7}$ Those particles are not blocked by the upper respiratory system and can deeply interact with the lungs. Although the bioavailability and toxicology of PGEs is still an open question, the determination of basal concentrations of those metals has a key role since 
an increase of their level. ${ }^{8,9}$ The heterogeneous composition of samples and the low concentration levels of palladium, platinum and rhodium involved make the direct measurement of analytes really difficult. Several analytical techniques have been employed with this matrix in recent years and most of the advantages and drawbacks have been reviewed. ${ }^{10-20}$ In previous work, some high performance liquid chromatography method for the determination of platinum group metals with derivatization has been reported. This has been proved to be a favorable and reliable technique. ${ }^{17-23}$ However, the routine chromatographic methods have some disadvantages. The used derivatization reagents can not react with palladium, platinum and rhodium simultaneously, ${ }^{17,18}$ or with low sensitivity, ${ }^{19,20}$ or need long time heating for a complete reaction. $^{23}$

In our previous work, 2,4-dihydroxybenzylidenethiorhodanine (DHBTR) was synthesized, and it color reaction noble metal ions was carefully studied. This reagent is high sensitivity for noble metal ions. ${ }^{24}$ In this paper, the DHBTR was used as pre-column derivatization regents for palladium, platinum and rhodium, and a ZORBAX Stable Bound analysis column $(4.6 \times 150 \mathrm{~mm}$, $5 \mu \mathrm{m}$ ) was used for the separation of Pd-DHBTR, PtDHBTR and Rh-DHBTR chelates on a high performance liquid chromatography equipped with on-line enrichment technique. This method can be applied to the determination $\mu \mathrm{g} \mathrm{L}^{-1}$ (ppb) level of palladium, platinum and rhodium ions in water, human urine and soil samples.

\section{Experimental}

\section{Apparatus}

On line column enrichment system used is shown in Figure 1. This system includes a Waters quadripump, Waters 515 pump, Waters 996 photodiode array detector, six ports switching valve, large volume injector (Sample loop is $10 \mathrm{~mL}$ ) and column. The enrichment column is ZORBAX Stable Bound pre-column $(4.6 \times 150 \mathrm{~mm}, 5 \mu \mathrm{m})$ and the analytical column is ZORBAX Stable Bound column $(4.6 \times 150 \mathrm{~mm}, 5 \mu \mathrm{m})$. The $\mathrm{pH}$ value was determined with a Beckman $\Phi-200$ pH meter.

\section{Chemicals}

All of the solutions were prepared with ultra-pure water obtained from a Milli-Q50 SP Reagent Water System (Millipore Corporation, USA). Palladium, platinum and rhodium standard solution $\left(1.0 \mathrm{mg} \mathrm{mL}^{-1}\right)$ was obtained from Chinese Standards Center, and a working solution

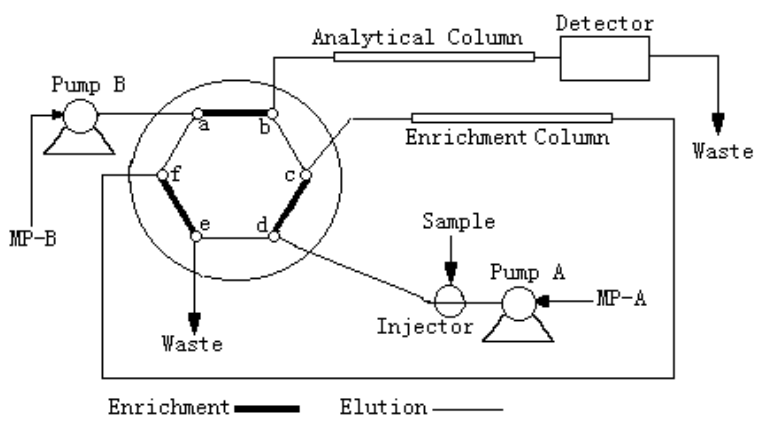

Figure 1. On-line enrichment system using the valve-switching technique Pump A, Waters 15 Pump. Pump B, Waters 2690 Alliance quadripump. Sample loop is $10 \mathrm{~mL}$. Six ports switching valve (Waters Corporation). Enrichment Column, ZORBAX $(4.6 \times 10 \mathrm{~mm}, 5 \mu \mathrm{m})$. Analytical column, ZORBAX $(4.6 \times 150 \mathrm{~mm}, 5 \mu \mathrm{m})$. Detector, Waters 996 photodiode array detector. MP A, $0.05 \mathrm{~mol} \mathrm{~L}^{-1}$ of $\mathrm{pH} 3.5$ sodium acetate-acetic acid buffer solution. MP B, $62 \%$ (v/v) acetonitrile (containing $0.05 \mathrm{~mol} \mathrm{~L}^{-1}$ of $\mathrm{pH}=3.5$ sodium acetate-acetic acid buffer salt and $0.1 \%$ of tritonX-100).

of $0.2 \mu \mathrm{g} \mathrm{mL}^{-1}$ was prepared by diluting this standard solution. HPLC grade acetonitrile was obtained from Fisher Corporation, USA. A sodium acetate-acetic acid buffer solution (0.5 mol L-1, pH 3.5) was used. The DHBTR was synthesized according to our previous work. ${ }^{24}$ and a DHBTR solution $\left(2.0 \times 10^{-4} \mathrm{~mol} \mathrm{~L}^{-1}\right)$ was prepared by dissolving DHBTR with $95 \%$ ethanol. Mobile phase A: $0.05 \mathrm{~mol} \mathrm{~L}^{-1} \mathrm{pH} 3.5$ sodium acetate-acetic acid buffer solution. Mobile phase B: $62 \%(\mathrm{v} / \mathrm{v})$ acetonitrile (containing $0.05 \mathrm{~mol} \mathrm{~L}^{-1}$ of $\mathrm{pH} 3.5$ sodium acetate-acetic acid buffer salt and $0.1 \%$ of tritonX-100). All other reagents used were of analytical reagent-grade. The glass and Teflon ware used were soaked in $5 \%$ of nitric acid for at least $2 \mathrm{~h}$, and then thoroughly wash with pure water.

\section{Spectrophotometric properties}

The absorption spectrum of metal-DHBTR chelates was obtained by measured with a Shimidzu UV-2401 spectrophotometer. Results show that the maximum absorption is $514 \mathrm{~nm}$ for Pd-DHBTR chelate, $518 \mathrm{~nm}$ for Pt-DHBTR and $512 \mathrm{~nm}$ for Rh-DHBTR chelate. Therefore, the $515 \mathrm{~nm}$ was selected as detecting wavelength. The molar absorptivity was calculated to be $8.21 \times 10^{4} \mathrm{~L} \mathrm{~mol}^{-1} \mathrm{~cm}^{-1}$ for Pt-HNTR chelate, $7.86 \times 10^{4} \mathrm{~L}$ $\mathrm{mol}^{-1} \mathrm{~cm}^{-1}$ for Pd-HNTR chelate, $6.85 \times 10^{4} \mathrm{~L} \mathrm{~mol}^{-1} \mathrm{~cm}^{-1}$ for Rh-HNTR chelate.

\section{Sample preparation}

For water and human urine samples, taking an appropriate volume (planting effluents $20 \mathrm{~mL}$, river water $200 \mathrm{~mL}$, human urine $50 \mathrm{~mL}$ ) of sample in a $500 \mathrm{~mL}$ flask. The samples were concentrated to about $5 \mathrm{~mL}$ by 
heating on a hot plate, and transferred into the $25 \mathrm{~mL}$ PTFE high-pressure microwave acid-digestion bomb (Fei Yue Analytical Instrument Factory, Shanghai, China). To which, $2.0 \mathrm{~mL}$ of concentrated nitric acid and $3.0 \mathrm{~mL}$ of $30 \%(\mathrm{v} / \mathrm{v})$ hydrogen peroxide was added. The bombs were sealed tightly and then positioned in the carousel of the microwave oven (Model WL 5001, 1000 W, Fei Yue Analytical Instrument Factory, Shanghai, China, twelve samples can be digested simultaneously). The system was operated at full power for $6.0 \mathrm{~min}$. The digest was evaporated to near dryness. The residue was dissolved with $5 \mathrm{~mL}$ of $5 \%(\mathrm{~m} / \mathrm{v})$ of hydrochloric acid and transferred into a $25 \mathrm{~mL}$ of calibrated flask quantitatively, then diluted the solution to volume with $5 \%(\mathrm{~m} / \mathrm{v})$ hydrochloric acid.

For soil samples, a $1.0000 \mathrm{~g}$ of sample was weighed into a $50 \mathrm{~mL}$ of PTFE high-pressure microwave aciddigestion bomb (Fei Yue Analytical Instrument Factory, Shanghai, China). To which, $10 \mathrm{~mL}$ of aqua regia was added. The bombs were sealed tightly and then positioned in the carousel of the microwave oven (Model WL 5001, 1000 W, Fei Yue Analytical Instrument Factory, Shanghai, China). The system was operated at full power for $30 \mathrm{~min}$. The digested material was evaporated to incipient dryness. Then, $10 \mathrm{~mL}$ of $5 \%(\mathrm{~m} / \mathrm{v})$ hydrochloric acid was added and heated close to boiling to leach the residue. After cooled, the residue was filtrated and the undissolved residue was washed with $5 \%(\mathrm{~m} / \mathrm{v})$ hydrochloric acid for 2 times. The leachate was collected into a $25 \mathrm{~mL}$ of calibrated flask quantitatively and diluted to the volume with 5\% hydrochloric acid.

\section{Standard procedure}

A $0 \sim 15 \mathrm{~mL}$ of $0.2 \mu \mathrm{g} \mathrm{mL}^{-1}$ standard or sample solution was transfered into a $25 \mathrm{~mL}$ of volumetric flask. To which, $4.0 \mathrm{~mL}$ of $1.0 \times 10^{-4} \mathrm{~mol} \mathrm{~L}^{-1}$ DHBTR solution, $3 \mathrm{~mL}$ of 0.5 mol L $\mathrm{L}^{-1}$ sodium acetate-acetic acid buffer solution $(\mathrm{pH}$ $3.5)$ and $1.0 \mathrm{~mL}$ of $1 \%(\mathrm{~m} / \mathrm{v})$ TritonX-100 solution were added. The solution was diluted to volume with water and mix well. After $10 \mathrm{~min}$, a $10.0 \mathrm{~mL}$ of solution was introduced into injector and sent to enrichment column with mobile phase A at flow rate of $2.0 \mathrm{~mL} \mathrm{~min}{ }^{-1}$. When the enrichment had finished, by switching the valve of six ports switching valve, the metal-DHBTR chelates, which absorbed onto the foreside of enrichment column, were eluted by mobile phase $B$ at the flow rate of $1.5 \mathrm{~mL}$ $\min ^{-1}$ in reverse direction and traveled towards the analytical column. The chelates were separated on the analytical column. A three-dimensional (X axis: retention time, $\mathrm{Y}$ axis: wavelength, $\mathrm{Z}$ axis: absorbance) chromatogram was recorded from $400 \sim 650 \mathrm{~nm}$ with photodiode array detector and the chromatogram of $515 \mathrm{~nm}$ is shown in Figure 2.

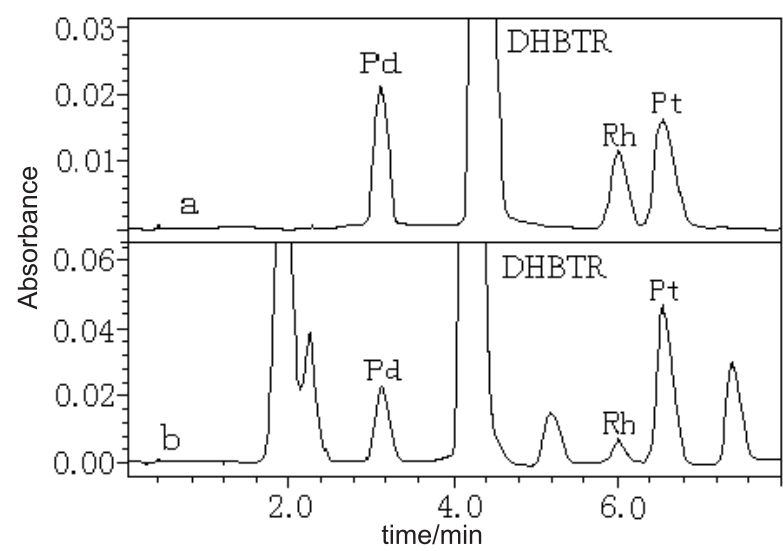

Figure 2. Chromatogram of standard sample (a) and Occupationally exposed human urine samples (b). The concentration of palladium and platinum is $1.0 \mathrm{mg} \mathrm{L}^{-1}$ in standard sample.

\section{ICP-MS analysis}

The ICP-MS analysis was carried out on a PlasmaQuad3 ICP-MS instrument (Micromass Corporation, UK) as described according to the liturature. ${ }^{24}$ The operating conditions as following: Frequency (MHz) 40.68; R.F. power (KW) 1.2; Sampling depth (mm) 12; Carrier flow $\left(\mathrm{L} \mathrm{min}^{-1}\right)$; Dwell time (ms) 100; Replicate accumulation 20; Channel Width 3; Replicate measurements 3.

\section{Result and Discussion}

\section{Precolumn derivation}

According to the literature, ${ }^{25}$ the optimal $\mathrm{pH}$ for the DHBTR reacts with metal ions is $1.6 \sim 5.2$ for palladium, $1.4 \sim 3.9$ for platinum, and $1.2 \sim 4.2$ for rhodium. Therefore, a pH 3.5 sodium acetate-acetic acid buffer solution $\left(0.5 \mathrm{~mol} \mathrm{~L}^{-1}\right)$ was recommended to control $\mathrm{pH}$.

The experiments show that $0.5 \mathrm{~mL}$ of $1.0 \times 10^{-4} \mathrm{~mol}$ $\mathrm{L}^{-1}$ DHBTR solution was sufficient to complex $5.0 \mathrm{mg}$ of palladium, platinum and rhodium, respectively. But in real samples, the foreign ions, such as $\mathrm{Hg}^{2+}, \mathrm{Pb}^{2+}, \mathrm{Cu}^{2+}, \mathrm{Ag}^{+}$ and the like, form complex with DHBTR and consume reagents. Therefore, the amount of DHBTR must be in excess. In this experiment, a $4.0 \mathrm{~mL}$ of $1.0 \times 10^{-4} \mathrm{~mol} \mathrm{~L}^{-1}$ DHBTR solution was recommended.

The experiments show that in the nonionic surfactants or cationic surfactants medium, the sensitivity of the metalDHBTR chelates was increased markedly. Various nonionic surfactants and cationic surfactants enhance the absorbance in the following sequence: TritonX-100 > Tween-80 > 
Tween-20 > CTMAB > CPB. Therefore, TritonX-100 was selected as additive in this experiment. The experiments show that the use of $0.6 \sim 1.4 \mathrm{~mL}$ of TritonX-100 solution give a constant and maximum absorbance in this experiment. Accordingly, $1.0 \mathrm{~mL}$ TritonX-100 solution was recommended in this experiment.

The experiment show that DHBTR can react with $\mathrm{Pd}(\mathrm{II}), \mathrm{Pt}(\mathrm{II})$ and $\mathrm{Rh}(\mathrm{III})$ rapidly at room temperature. The reaction was complete for $5 \mathrm{~min}$ at room temperature, and the complex was stable for at least $6 \mathrm{~h}$.

\section{On-line enrichment}

Because the Pd-HNMTD and Pt-HNMTD chelates are stable in weak acid medium. To avoid the chelates decomposing during the enrichment, a $0.05 \mathrm{~mol} \mathrm{~L}^{-1}$ of sodium acetate-acetic acid buffer solution of $\mathrm{pH} 3.5$ (mobile phase A) was selected as mobile phase to send the chelates to the enrichment column and a ZORBAX Reversed Phase Stable Bound $\mathrm{C}_{18}$ pre-column $(4.6 \times 10 \mathrm{~mm}, 5 \mu \mathrm{m})$ with $\mathrm{pH}$ range 1 11.5 was selected as enrichment column.

The aim of the present research was to determine trace metal ions by injecting a large volume of sample. Therefore, the effect of the injection volume was investigated. The proper injection volume is $0.1 \sim 20 \mathrm{~mL}$. If the injection volume was over $20 \mathrm{~mL}$, the chromatographic peaks were obviously broadened or the enrichment column would be overloaded. The volume of $10 \mathrm{~mL}$ sample injected was sensitive enough to determine palladium and platinum in samples of this experiment, and $10 \mathrm{~mL}$ sample injection was recommended.

\section{Chromatographic separation}

The experiments showed that the Pd-DHBTR, PtDHBTR and Rh-DHBTR chelates have a good stability in the presence of weak acid buffer solution and TritonX-100 medium. The $\mathrm{pH}$ of mobile phase within $2.9 \sim 3.8$ and containing a $0.05 \% \sim 0.2 \%$ of TritonX-100 in the mobile phase can avoid the metal-chelate decomposing in the course of separation and get a good peak shape. So acetonitrile/water $\left(62 / 38, \mathrm{v} / \mathrm{v}\right.$ ) (containing $0.05 \mathrm{~mol} \mathrm{~L}^{-1}$ of $\mathrm{pH} 3.5$ sodium acetate-acetic acid buffer salt and $0.1 \%$ of tritonX-100) was selected as mobile phase, and a ZORBAX Stable Bound analysis column $(4.6 \times 150 \mathrm{~mm}, 5 \mu \mathrm{m})$ was selected as analytical column in this experiment.

\section{Calibration graphs}

Under optimum conditions, the regression equations of metal-DHBTR chelates were established based on the standard sample injected and its peak areas. The Limits of detection were calculated according to the IUPAC recommendation ( $(3 \mathrm{x}$ standard deviation blank) / (slope of the analytical calibration curve)). The results were shown in Table 1 . The reproducibility of this method was also examined for $10 \mu \mathrm{g} \mathrm{L}^{-1}$ of $\mathrm{Pd}(\mathrm{II}), \mathrm{Pt}(\mathrm{II})$ and $\mathrm{Rh}(\mathrm{III})$. The relative standard deviations $(n=11)$ were also shown in Table 1.

\section{Interference}

According to the literature, ${ }^{25}$ the pre-column derivatization conditions, the foreign ions of $\mathrm{Cu}$ (II), $\mathrm{Hg}$ (II), $\mathrm{Pb}(\mathrm{II}), \mathrm{Tl}(\mathrm{III}), \mathrm{Bi}(\mathrm{III}), \mathrm{Ag}(\mathrm{I}), \mathrm{Au}(\mathrm{III})$ which can reacts with DHBTR to form color chelates. To examine the selectivity of this method, the interference of these foreign ions was investigated. When $4.0 \mathrm{~mL}$ of $1.0 \times 10^{-4} \mathrm{~mol} \mathrm{~L}^{-1}$ DHBTR was used, with $10 \mu \mathrm{g} \mathrm{L}^{-1}$ of $\mathrm{Pd}(\mathrm{II}), \mathrm{Pt}(\mathrm{II})$ and $\mathrm{Rh}(\mathrm{III})$ respectively, the tolerance amount with an error of $\pm 5 \%$ was $2000 \mu \mathrm{g} \mathrm{L}^{-1}$ for $\mathrm{Cu}(\mathrm{II}), \mathrm{Hg}(\mathrm{II}), \mathrm{Pb}(\mathrm{II}), \mathrm{Ag}(\mathrm{I})$ and 800 $\mu \mathrm{g} \mathrm{L}^{-1}$ for $\mathrm{Tl}(\mathrm{III}), \mathrm{Bi}(\mathrm{III}), \mathrm{Au}(\mathrm{III})$.

\section{Application}

This method was applied to determination of palladium, platinum and rhodium in water, human urine and soil samples. The samples were prepared according to the sample preparation section, and the palladium, platinum and rhodium contents were analyzed by using a proper volume of this solution according to general procedure. The results (deducted the reagents blank) were also shown in Table 2. An ICP-MS method as described according to the literature ${ }^{24}$ was used as reference method. The results were also shown in Table 3 .

\section{Conclusions}

The proposed method has the following characteristic: DHBTR is a sensitive and convenience pre-column derivatization regents for palladium, platinum and rhodium. By on-line enrichment system, a large volume of sample (10 $\mathrm{mL}$ ) can be injected, and the sensitivity of the method was

Table 1. Limits of detection and linear correlation coefficients

\begin{tabular}{|c|c|c|c|c|c|}
\hline Components & Regression Equation & Linearity Range (ng L ${ }^{-1}$ ) & Coefficient & Limits of Detection / $\left(\mathrm{ng} \mathrm{L} \mathrm{L}^{-1}\right)$ & $\operatorname{RSD} \%(\mathrm{n}=11)$ \\
\hline Pd-DHBTR & $\mathrm{A}=4.58 \times 10^{6} \mathrm{C}-1542$ & $12 \sim 8500$ & $\mathrm{r}=0.9989$ & 3.6 & 2.5 \\
\hline Pt-DHBTR & $\mathrm{A}=4.32 \times 10^{6} \mathrm{C}-1647$ & $14 \sim 7600$ & $r=0.9991$ & 3.2 & 2.9 \\
\hline Rh-DHBTR & $\mathrm{A}=4.16 \times 10^{6} \mathrm{C}+143$ & $18 \sim 9400$ & $r=0.9989$ & 4.5 & 2.7 \\
\hline
\end{tabular}


Table 2. Determination results of the samples by the proposed method

\begin{tabular}{|c|c|c|c|c|c|c|c|c|c|}
\hline \multirow[t]{2}{*}{ Samples } & \multicolumn{3}{|c|}{ Found } & \multicolumn{3}{|c|}{$\mathrm{RSD} \%(\mathrm{n}=5)$} & \multicolumn{3}{|c|}{ Recovery\% $(\mathrm{n}=5)$} \\
\hline & $\mathrm{Pt}$ & $\mathrm{Pd}$ & $\mathrm{Rh}$ & $\mathrm{Pt}$ & $\mathrm{Pd}$ & $\mathrm{Rh}$ & $\mathrm{Pt}$ & $\mathrm{Pd}$ & $\mathrm{Rh}$ \\
\hline Human Urine ${ }^{a}$ (Occupationally exposed) & 0.658 & 0.246 & 0.152 & 2.8 & 3.1 & 3.2 & 93 & 91 & 94 \\
\hline Planting effluents a & 0.826 & 1.832 & 0.185 & 3.0 & 3.1 & 3.3 & 92 & 93 & 89 \\
\hline Soil ${ }^{b}$ (Nearby the highway) & 72.1 & 93.4 & 28.5 & 3.5 & 2.9 & 3.4 & 94 & 93 & 91 \\
\hline
\end{tabular}

${ }^{\mathrm{a}} \mu \mathrm{g} \mathrm{L}^{-1} ;{ }^{\mathrm{b}} \mathrm{ng} \mathrm{g}^{-1}$.

Table 3. Determination results of the samples by the ICP-MS method

\begin{tabular}{|c|c|c|c|c|c|c|c|c|c|}
\hline \multirow[t]{2}{*}{ Samples } & \multicolumn{3}{|c|}{ Found } & \multicolumn{3}{|c|}{$\mathrm{RSD} \%(\mathrm{n}=5)$} & \multicolumn{3}{|c|}{ Recovery\% ( $\mathrm{n}=5)$} \\
\hline & $\mathrm{Pt}$ & $\mathrm{Pd}$ & $\mathrm{Rh}$ & $\mathrm{Pt}$ & $\mathrm{Pd}$ & $\mathrm{Rh}$ & $\mathrm{Pt}$ & $\mathrm{Pd}$ & $\mathrm{Rh}$ \\
\hline Human Urine ${ }^{a}$ (Occupationally exposed) & 0.642 & 0.263 & 0.175 & 3.1 & 3.4 & 3.6 & 92 & 88 & 89 \\
\hline Planting effluents a & 0.839 & 1.841 & 0.178 & 3.3 & 3.2 & 3.5 & 86 & 91 & 87 \\
\hline Soil ${ }^{\mathrm{b}}$ (Nearby the highway) & 70.2 & 95.8 & 26.9 & 3.4 & 3.6 & 3.8 & 84 & 94 & 86 \\
\hline
\end{tabular}

${ }^{\mathrm{a}} \mu \mathrm{g} \mathrm{L}^{-1} ;{ }^{\mathrm{b}} \mathrm{ng} \mathrm{g}^{-1}$.

greatly improved. The Limits of detection of palladium, platinum and rhodium are $3.6 \mathrm{ng} \mathrm{L}^{-1}, 3.2 \mathrm{ng} \mathrm{L}^{-1}$ and $4.5 \mathrm{ng}$ $\mathrm{L}^{-1}$, respectively. For the determination of palladium, platinum and rhodium in water, human urine and soil sample, the relative standard deviations for five replicate samples are 2.8-3.5\% for platinum, $2.9-3.1 \%$ for palladium, $3.2-3.4 \%$ for rhodium. The standard recoveries are $92-94 \%$ for platinum, $91-93 \%$ for palladium, $89-94 \%$ for rhodium. The determination results agree with the reference method (ICP-MS method). The relative standard deviations and the standard recoveries are better then that of reference method. The results are satisfactory.

\section{Acknowledgments}

This work was supported by the National Natural Science Foundation of China (20471051) and the Key Natural Science Foundation of Yunnan Province (2005K021).

\section{References}

1. Farago, M. E.; Kavanagh, P.; Blanks, R.; Kelly, J.; Kazantzis, G.; Thornton, I.; Simpson, P.R.; Cook, J. M.; Delves, H. T.; Hall, G. E. M.; Analyst 1998, 123, 451.

2. Wei, C.; Morrison, G. M.; Sci. Total Environ. 1994, 146-147, 169.

3. Lucena, P.; Vadillo, J. M.; Laserna, J. J.; Anal. Chem. 1999, 71, 4385.

4. Helmes, E.; Environ. Sci. Pollut. Res. 1997, 4, 100.

5. Savchenko, V. I.; Makaryan, I. A.; Platinum Metals Rev. 1999, $43,74$.

6. Flynn, P. C.; Wanke, S. E.; J. Catal. 1975, 37, 432.

7. Wynblatt, P.; Gjostein, N. A.; Prog. Solid State Chem. 1975, 9 , 22.

8. Konig, H.; Hertel, R.; Rosner, G.; Atmos. Environ. 1992, 26A, 741.
9. Palacios, M. A.; Gomez, M.; Sci. Total Environ. 2000, 182, 1.

10. Balcerzac, M.; Analyst 1997, 122, 67R.

11. Georgieva, M.; Pihlar, B.; Fresenius'J. Anal. Chem. 1997, 357, 874.

12. Godlewska-Zylkiewicz, B.; Zaleska, M.; Anal. Chim. Acta 2002, 462, 305.

13. Krachler, M.; Alimonti, A.; Petrucci, F.; Irgolic, K. J.; Forastiere, F.; Caroli, S.; Anal. Chim. Acta 1998, 363, 1.

14. Jacubowski, N.; Feldmann, I.; Stuewer, D.; Spectrochim. Acta, Part B 1992, 47, 107.

15. Wollenweber, D.; Straaburg, S.; Wunsch, G.; Fresenius'J. Anal. Chem. 1999, 364, 433.

16. Boulyga, S. F.; Dietze, H. J.; Becker, J. S.; Mikrochim. Acta 2001, 137, 93.

17. Philippeit, G.; Angerer, J.; J. Chromatogr., B. 2001, 760, 237.

18. Gregurek, D.; Reimannb, C.; Stump, E. F.; Environ. Pollut. 1998, 102, 221.

19. Parent, M.; Vanhoe, H.; Moens, L.; Dams, R.; Fresenius' J. Anal. Chem. 1996, 354, 664.

20. Bruzzoniti, M. C.; Cavalli, S.; Mangia, A.; Mucchino, C.; Sarzanini, C.; Tarasco, E.; J. Chromatogr., A. 2003, 997, 51.

21. Barefoot, R. R.; Vanloon, J. C.; Anal. Chim. Acta 1996, 334, 5.

22. Hoshi, S.; Higashihara, K.; Suzuki, M.; Sakurada, Y.; Talanta 1997, 44, 571

23. Wang, H.; Zhang, H. S.; Cheng, J. K.; Talanta 1999, 48, 1.

24. Dong, S. A.; Chen, J.; Wu, R. L. Analysis Methods of Precious Metals, $1^{\text {st }}$ ed.; Chinese Science Press: Beijing, P.R. China, pp. 263-268, 2004

25. Yang, G. Y.; Hu, Q. F.; Yin, J. Y.; J. Chinese Chem. Agent (Huaxue Shiji) 2004, 26, 248

26. Yang, G.; Hu, Q.; Huang, Z.;Yin, J.; J. Braz. Chem. Soc. 2005, $6 A, 1154$.

Received: March 30, 2005 Published on the web: January 13, 2006 